\title{
PROTEKSI TERHADAP HAK KESELAMATAN TENAGA KERJA BERLATAR MULTI AGAMA DALAM PERSPEKTIF ISLAM DAN HAM
}

\author{
Bambang Satriya \\ Universitas Merdeka Malang \\ Jl.Terusan Dieng No. 62 Malang \\ Email : satriyash.mh_p@yahoo.co.id
}

\begin{abstract}
Abstrak
Salah satu kepentingan asasi setiap tenaga kerja adalahhak atas keselamatan. Sayangnya, keselamatan tenaga kerja Indonesia masih menjadi hak yang maksimal untuk dilindungi. Dalam kenyataan, tidak sulit ditemukan sejumlah peristiwa atau kasus tentang kecelakaan tenaga kerja. Pekerja menjalankan pekerjaan dengan resiko yang tinggi, yang tidak sedikit mengakibatkan hak keselamatannya terancam atau hilang. Banyak ditemukan bukti tentang sejumlah perusahaan atau korporasi yang mempekerjakan karyawan atau pekerjanya tanpa memperhatikan aspek keselamatannya. Disinilah pelanggaran terhadap hak asasi tenaga kerja terjadi yang dilakukan oleh korporasi. Dalam Islam maupun aspek hak asasi manusia, pelanggaran ini sebagai perbuatan yang tidak manusiawi.
\end{abstract}

Kata kunci: tenaga kerja, keselamatan, korporasi, negara, Islam, hak asasi manusia

\section{Abstract}

One of the fundamental interests of every workforce is the right to safety. Unfortunately, the safety of Indonesian workers is still the maximum right to be protected. In reality, it is not difficult to find a number of events or cases concerning labor accidents. Workers carry out work with high risk, which does not in the least cause their safety rights to be threatened or lost. Much evidence is found about a number of companies or corporations that employ their employees or workers without regard to safety aspects. This is where violations of labor rights occur committed by corporations. In both Islam and human rights aspects, this violation is an inhumane deed.

Keywords: labor, safety, corporation, state, Islam, human rights

\section{PENDAHULUAN}

Manusia memenuhi kebutuhan hidup untuk kelangsungan hidupnya di dunia. Untuk itu manusia perlu bekerja, sebab dengan bekerja manusia akan memanusiakan dirinya sebagai makhluk Allah yang paling sempurna 
dari seluruh ciptaanNya. Baharuddin Lopa (1996) menyebut, bahwa bekerja merupakan hak setiap manusia dewasa sebagai upaya menjaga derajat kemanusiaan dan memenuhi kebutuhan hidup. Negara dan masyarakat harus menjamin hak setiap manusia atau warga negara untuk bekerja dan tidak membedakan hak tersebut antara satu dengan lainnya. ${ }^{1}$

Hal itu menunjukkan, bahwa dalam hidup ini manusia membutuhkan pekerjaan. Dengan pekerjaan yang dilaksanakan, manusia dapat memenuhi berbagai kebutuhan hidupnya. Sebab, dari pekerjaan yang dilakukan itu, manusia mendapatkan penghasilan. Sebagai hak manusia, maka pekerjaan dapat menentukan besarnya penghasilan. Sedangkan penghasilan ini juga menjadi hal yang harus dimilikinya setelah manusia menjalankan pekerjaan.

Begitu pentingnya bekerja atau pekerjaan bagi kehidupan manusia hingga kompetisi untuk memperebutkannya sangat ketat, bahkan tidak sedikit diantarannya yang terpaksa ditempuh dengan cara-cara yang melanggar norma-norma agama dan hukum yang berlaku, seperti untuk mendapatkan pekerjaan, seseorang menempuhnya dengan cara menyuap atau menjual harga diri.

Vitalnya persoalan pekerjaan itu dapat dikaitkan dengan tanggungjawab pekerja yang tidak hanya untuk kepentingan dirinya, tetapi juga untuk kepentingan atau kelangsungan hidup banyak pihak, seperti ada anak, isteri, dan orang lain yang menjadi tanggungjawabnya dan mengharapkan peran-perannya secara ekonomi.

Di dalam UDHR (Universal Declaration of Human Rights) pasal 23 ayat 1,2, 3, dan 4 disebutkan: (1) Setiap orang berhak untuk memperoleh pekerjaan, bebas memilih pekerjaan, syarat-syarat yang adil, dan menyenangkan dari suatu lingkungan pekerjaan dan mendapat perlindungan dari pengangguran, (2) setiap orang tanpa dibeda-bedakan berhak memperoleh upah yang sama atas pekerjaan yang sama, (3) setiap orang yang bekerja berhak akan imbalan yang adil dan menyenangkan, yang menjamin dirinya sendiri dan keluarganya sesuai dengan kemuliaan martabat manusia dan ditambah pula bila perlu dengan bantuan-bantuan sosial lainnya, dan (4) setiap orang berhak untuk membentuk dan bergabung dengan serikat-serikat pekerja untuk melindungi kepentingankepentingannya.

Lingkungan dan kondisi yang menyenangkan bagi tenaga kerja merupakan salah satu kebutuhan vitalnya. Tenaga kerja akan bisa menjalankan pekerjannya atau kewajibannya dengan baik jika didukung

1 Jazila Nasuha, Perlindungan Islam terhadap Tenaga Kerja yang Bekerja di Pasar Global, (Jakarta: Hifagroup, 2014), hal. 21. 
oleh lingkungan kerja yang baik pula. Ketika kondisi lingkungan pekerjaannya tidak menyenangkan, apalagi rawan dengan ancaman yang membahayakan kesehatan, apalagi keselamatannya, maka hal ini dapat dinilai sebagai kondisi yang yang tidak mendukung.

Fenomena di seputar ketenagakerjaan dewasa ini adalah masih banyaknya lingkungan kerja, termasuk di dalamnya manajemen kerja yang mengandung potensi kerawanan yang membahayakan atau menimbulkan berbagai bentuk kecelakaan kerja. Tidak sedikit perusahaan yang mempunyai manajemen kerja yang mengabaikan keselamatan kerja. Misalnya tenaga kerja meninggal dunia atau mengalami cacat kerja pada saat atau sedang menjalankan kewajibannya.

Secara umum dijelaskan Teten Masduki sebagaimana dikutip E Shobirin Nadj dan Naning Mardiniah (2000), bahwa di bawah kebijakan politik dan ekonomi nasional, pertimbangan hak-hak buruh saat ini menghadapi persoalan yang sangat rumit. Bukan rahasia, buruh di tanah air ini sangat rentan kehilangan pekerjaan dan sulit mendapatkan gantinya, menerima upah paling rendah di antara negara-negara tetangga, setiap dua hari seorang buruh tewas, dan senantiasa harus menghadapi tekanandan teror dari aparat keamanan. ${ }^{2}$

Kondisi tersebut layak untuk disikapi dalam perspektif Islam dan Hak Asasi Manusia (HAM). Kedua pendekatan ini penting, mengingat, pertama, mayoritas tenaga kerja di Indonesia ini memang umat Islam, namun tidak sedikit diantaranya yang berasal dari agama yang bermacammacam (multi agama) dan kedua, problem HAM telah atau sedang menjadi alasan utama untuk memperjuangkan nasib tenaga kerja di Indonesia.

\section{METODE PENELITIAN}

Jenis penelitian yang digunakan dalam penelitian ini menggunakan jenis penelitian normatif. Penelitian normatif adalah penelitian yang mencakup penelitian terhadap asas-asas, sistematika, sinkhronisasi, sejarah, dan perbandingan dalam bidang yang jadi pembahasan. ${ }^{3}$ Pendekatan penelitian yang digunakan dalam penelitian ini menggunakan jenis pendekatan: a) pendekatan Perundang-undangan (Statute Approach), ${ }^{4}$ dan 2) pendekatan konseptual (Conceptual Approach). ${ }^{5}$

${ }^{2}$ Haekal Madani, Hak-hak Buruh dalam Berbagai Perspektif, (Jakarta: Miqrab Media, 2015), hal. 15.

${ }^{3}$ Soerjono Soekanto, Pengantar Penelitian Hukum, (Jakarta, UI Press: 1981), 51. 2010), 137

${ }^{4}$ Peter Mahmud Marzuki, Penelitian Hukum, (Jakarta, Prenada Media Group,

${ }^{5}$ Ibid, hlm. 166. 
Teknik analisis bahan yang digunakan dalam penelitian ini adalah teknik analisis deskriptif terhadap sistematika pembahasan. Kerangka acuan yang dipergunakan adalah kesesuaian dengan permasalahan yang dikaji dalam penelitian ini. Metode yang digunakan adalah metode berpikir deduktif, yaitu metode berpikir yang penarikan kesimpulannya ditarik dari sesuatu yang bersifat umum yang sudah dibuktikan dengan benar dan kemudian kesimpulannya dijabarkan secara khusus

\section{PEMBAHASAN \\ Perspektif Islam}

Di dalam Deklarasi OKI pasal 13 juga disebutkan, bahwa "bekerja adalah hal yang dijamin oleh pemerintah dan masyarakat untuk setiap orang yang siap untuk bekerja. Setiap orang harus bebas untuk memilih pekerjaan yang paling sesuai dan berguna bagi dirinya dan masyarakat".

Di dalam Al-Qur'an juga disebutkan "Dan katakanlah: "bekerjalah kamu, maka Allah dan Rosul-Nya serta orang-orang mukmin akan melihat pekerjaannya itu, dan kamu akan dikembalikan kepada (Allah) Yang Mengetahui akan yang ghaib dan nyata. Lalu diberitakan-Nya kepada kamu apa yang telah kamu kerjakan (QS At-Taubah: 105).

Di dalam Hadist disebutkan "berikanlah upah seorang buruh sebelum kering keringatnya, dan berikanlah upahnya sewaktu dia bekerja". (HR Al-Bayhaqi). Hadis ini menunjukkan perhatian yang cukup besar terhadap seseorang yang menjalankan kegiatan berupa "kerja". Dengan bekerja, seseorang diberi hak, yang salah satunya bernama "upah", yang kedudukan hukumnya adalah wajib untuk ditegakkan, dan bahkan penegakannya atau pelaksaannya tidak boleh ditunda-tunda.

Selain hak upah itu, tenaga kerja juga berhak atas hak lainnya, seperti hak perlindungan terhadap kesehatan dan keselamatan dirinya. Dijelaskan dalam suatu hadis yang berbunyi "berikanlah makan, minum, pakaian kepada buruhmu sebagaimana kamu kamu makan, minum dan berpakaian". Artinya, tenaga kerja berhak untuk dijaga atau dilindungi oleh perusahaan sebagaimana layaknya perusahaan menjaga dan melindungi kepentingannya, seperti keselamatan perusahaan.

Jika ditafsirkan, kalau perusahaan itu punya orientasi tidak hanya sekedar makan, minum, dan pakaian, tetapi juga keselamatan usaha dan aset-asetnya, maka perusahaan juga punya kewajiban melindungi kesehatan dan keselamatan tenaga kerja. Melindungi kesehatan dan keselamatan tenaga kerja sama halnya dengan menjaga kesehatan dan keselamatan perusahaan.

Dalam Hadis lain juga disebutkan "pedagang yang jujur akan dihimpun pada hari kiamat bersama dengan orang-orang yang benar dan 
suhada' (Imam Al-Ghazali, 2003). Hadis ini menunjukkan bahwa perusahaan wajib menunjukkan sikap kejujurannya dalam menjalin hubungan kerja dengan tenaga kerja yang menyangkut hak-hak tenaga kerja. Perusahaan tidak boleh membohongi atau berbuat curang terhadap hakhaknya. ${ }^{6}$

Ketika dilakukan transaksi atau perjanjian kerja antara perusahaan dengan tenaga kerja, maka perusahaan berkewajiban menunjukkan hak-hak tenaga kerja dengan jujur. Kejujuran yang dilakukan perusahaan ini menjadi prinsip utama yang bisa menguatkan posisi tenaga kerja. Tenaga kerja akan terhambat dan bisa kehilangan hak-hak asasinya ketika perusahaan sering melakukan ketidakjujuran.

"Berikan upah kepada pekerjamu (buruhmu) sebelum keringatnya menetes" atau "berikanlah pakaian dan makan kepada pekerjamu sebagaimana apa yang engkau makan dan pakai”, adalah diantara sabda Nabi Muhammad SAW, yang mewajibkan kepada setiap majikan, tuan, atau perusahaan untuk menunjukkan sikap dan perilaku responsibilitasnya terhadap pekerjanya.

Pekerja, buruh, pelayan, pembantu, atau pegawai yang melakukan pekerjaan untuk majikan, tuan, atau perusahaan, telah ditempatkan oleh agama (Islam) sebagai subyek yang wajib dimanusiakan, baik dalam aspek "kewajiban" maupun "hak".

Dalam Hadis itu juga dapat dipahami, bahwa buruh atau pekerja, apapun agamanya wajib hukumnya untuk diperlakukan secara manusiawi. Mulai dari sandang, pangan, dan kebutuhan buruh lainnya, majikan atau tuan (perusahaan) terikat secara moral keagamaan untuk memenuhinya.

Dalam dimensi kewajiban, pekerja atau buruh berlatar multi agama sudah otomatis terikat kontrak kerja yang harus dilaksanakan atau diselesaikan, karena dari kewajiban yang dilaksanakan ini, apa yang ditunjukkan oleh buruh atau pekerja akan memberikan nilai tambah, keuntungan, dan memediasi kemaslahatan majikan atau tuannya.

Masyarakat semestinya paham, bahwa majikan, tuan, atau perusahaan membutuhkan kehadiran buruh, yang nota bene berarti menggantungkan peran-peran yang dilakukan oleh buruh untuk mengurai, memberi solusi, dan setidak-tidaknya meringankan problem yang dihadapinya.

Begitu tenaga kerja tersebut hadir dengan peran-perannya, sang majikan atau perusahaan mendapatkan konstribusi besar untuk keluar dari problemnya. Mereka bukan hanya mendapatkan suntikan kekuatan besar,

${ }^{6}$ Abdul Wahid, dkk, "Perlindungan Tenaga Kerja Indonesia dalam Kajian Agama Islam”, Lembaga Kajian dan Pengembangan Sumberdaya Manusia, 15 Mei 2016, 5. 
tetapi juga dapat memperoleh keuntungan besar baik secara ekonomi, eksistensi diri, prospek korporasi maupun lainnya. ${ }^{7}$

Dalam realitas seringkali terjadi kondisi yang kurang atau tidak menyenangkan Ketika berelasi dengan kewajiban. Di dalam aspek kewajiban ini, majikan semestinya juga harus mempertimbangkan sisi manusiawi untuk mengukur antara realitas kemampuan fisik maupun nonfisik yang melekat dalam diri tenaga kerja dibandingkan dengan kewajiban yang dibebankan kepadanya. Jika kemampuan buruh tidak cukup kapabel (distandarkan dengan kondisi dan situasi) untuk menjalankan kewajiban, maka selayaknya majikan tidak meneruskan ke tahap eksploitasi, apalagi sampai mentolelir terjadinya praktik-praktik dehumanisasi (baca: peniadaan penghormatan terhadap harkat kemanusiaan). ${ }^{8}$

Ada kecenderungan yang sering mencuat di tengah masyarakat, bahwa tatkala tenaga kerja berlatar multi agama sudah terikat kontrak kerja, maka apa yang sudah masuk dalam materi kontrak tersebut harus mutlak dilaksanakan atau dipenuhi oleh buruh. Ironisnya lagi, apa yang tidak ada di luar kontrak kerja ini seringkali juga dipaksakan oleh majikan supaya dilakukan oleh buruh. Pemaksaan ini bahkan tidak sedikit yang bersifat penodaan terhadap harkat kemanusiaan buruh, seperti PRT (Pembantu Rumah Tangga) yang dilecehkan secara seksual oleh majikannya atau dijebak dan dituding mencuri oleh majikannya, yang ujung-ujungnya sang majikan punya maksud menjadikannya sebagai obyek pelampiasan seksual atau pekerjaan-pekerjaan lain yang tidak mengandung kompensasi upah.

Selain aspek kewajiban yang harus mendapatkan perhatian istimewa dari majikan, aspek hak juga wajib diperhatikannya. Repotnya sekarang, ada kecenderungan di kalangan majikan, tuan, atau perusahaan yang tidak maksimal dalam memperhatikan hak tenaga kerja berlatar multi agama. Hak pengupahan, hak mendapatkan perlindungan kesehatan dan keselamatan kerja, hak jaminan paska kerja, dan hak-hak strategis lainnya, seringkali diabaikan atau setidaknya dibikin "merana" oleh majikan, tuan, atau perusahaan.

Bedasarkan kasus tersebut, buruh masih tidak ubahnya obyek yang diperlakukan sebagai kumpulan manusia yang diperas tenaga atau keringatnya, sementara hak-haknya dipinggirkan. Mereka hanya mau mengambil keuntungan dari peran strategis buruh, sementara hak-haknya ditanggalkan, atau kalaupun ada perlakuan yang berkenaan dengan hak-hak tenaga kerja yang bisa ditunjukkannya, mereka tetap menjadikan tenaga kerja sebagai segmentasi yang tidak berdaya yang identik berstatus

\footnotetext{
${ }^{7}$ Haekal Madani, , Op.Cit, 12.

${ }^{8}$ Abdul Wahid, dkk, Op.Cit, 6.
} 
"korban". Hal inilah yang dalam Islam dilarang keras, meskipun tenaga kerja atau pekerja ini agamanya bermacam-macam atau berlatar multi agama.

\section{PERSPEKTIF HAM}

Dalam pasal 28E Undang-Undang Dasar 1945 (Undang-Undang Dasar 1945 yang diamandemen) disebutkan, bahwa setiap orang bebas memeluk agama dan beribadat menurut agamanya, memilih pendidikan dan pengajaran, memilih pekerjaan, memilih kewarganegaraan, memilih tempat tinggal di wilayah negara dan meninggalkannya, serta berhak kembali.

Indonesia adalah Negara yang sedang berkembang, yang tentunya perkembangan perekonomiannya juga masih membutuhkan peningkatan dalam sistem perekonomian yang berlaku di Indonesia. Salah satu penggerak roda perekonomian adalah tenaga kerja. Sejak Negara ini didirikan, bangsa Indonesia telah menyadari bahwa pekerjaan merupakan kebutuhan asasi warga Negara sebagaimana diamanatkan dalam Pasal 27 Ayat (2) Undang-Undang Dasar Tahun 1945 yang menyatakan "tiap-tiap warga Negara berhak atas pekerjaan dan penghidupan yang layak bagi kemanusiaan. ${ }^{9}$

Ketentuan konstitusi tersebut menunjukkan, bahwa salah satu HAM adalah hak untuk mencari, mendapatkan, dan memilih pekerjaan yang sesuai dengan keinginan atau barangkali bidang keilmuan dan ketrampilannya. Pekerjaan ini tidak menempatkan latar multi agama bagi setiap tenaga kerja.

Jenis pekerjaan merupakan salah satu aktivitas yang dapat memberikan manfaat secara ekonomi bagi seseorang. Melalui aspek ekonomi yang didapatkan dari pekerjaan yang dilakukannya ini, seseorang dapat meningkatkan taraf kehidupannya, seperti hak membebaskan diri dari kehidupan yang serba kesulitan menjadi kehidupan yang berkecukupan, dari kehidupan yang mengalami kemiskinan diperbaharui ke taraf kehidupan yang sejahtera.

Pekerjaan mempunyai makna yang sangat penting dalam kehidupan manusia sehingga setiap orang membutuhkan pekerjaan. Pekerjaan dapat dimaknai sebagai sumber penghasilan seseorang untuk memenuhi kebutuhan hidup bagi dirinya sendiri dan keluarganya, dapat juga dimaknai sarana mengaktualisasikan diri sehingga seseorang hidupnya menjadi lebih berharga baik untuk dirinya sendiri maupun bagi orang lain. Kehidupan dan pekerjaan adalah dua sisi dari satu mata uang, agar orang bisa hidup maka orang harus bekerja.

\footnotetext{
${ }^{9}$ Adrian Sutedi, Hukum Perburuhan, (JakartaL Sinar Grafika, 2009), 1.
} 
Dalam ayat 1 pasal 1 Undang-undang Nomor 39 Tahun 1999 tentang Hak Asasi Manusia disebutkan, bahwa hak asasi manusia adalah seperangkat hak yang melekat pada hakikatnya dan keberadaan manusia sebagai makhluk Tuhan Yang Maha Esa dan merupakan anugerah-nya yang wajib dihormati, dijunjung tinggi dan dilindungi oleh negara, hukum, Pemerintah, dan setiap orang demi kehormatan serta perlindungan ahrkat dan martabat manusia. ${ }^{10}$

Dalam kedudukannya sebagai hak asasi itu, tentu saja setiap manusia Indonesia menjadi tergantung pekerjaan itu. Bahkan disebut pula, kalau salah satu tolok ukur kesuksesan seseorang dalam hidup ini, terutama dibidang ekonomi adalah terletak pada jenis pekerjaan apa yang sedang dijalankannya. Berawal dari pekerjaan, seseorang dapat menikmati kesejahteraan, dan dengan hilannya pekrjaan pula, seseorang dapat terlempar ke jurang kemiskinan, dan bahkan kegiatan-kegiatan yang melanggar hukum dan norma agama. Berawal dari pekerjaan yang dapat membuahkan kekayaan banyak, seseorang bukan hanya dapat menjadi orang terpandang, tetapi juga dapat berbuat banyak untuk kepentingan daerah, lingkungan alam, dan sesama manusia yang membutuhkan manfaat dari pekerjaannya.

Di dalam Universal Declaration of Human Rights (UDHR) atau Deklarasi Umum Hak Asasi Manusia pada prinsipnya menyebutkan bahwa setiap orang mempunyai hak untuk hidup, bebas, merdeka, dan keamanan pribadi.

Deklarasi tersebut lahir sebagai acuan masyarakat internasional karena sebelumnya manusia hanya sebagai objek hukum rimba di tangan komunitas elit yang kuat. Masyarakat tidak ubahnya hanya raga-raga mati yang tidak bernyawa karena nasibnya ditentukan oleh raja, penguasa, atau kroni-kroni penguasa yang berpengaruh besar dalam melahirkan keputusan politik primordialisme sebagai hukum itu sendiri.

Saat sebelum lahir deklarasi itu, manusia atau rakyat tidak lebih dari kumpulan pribadi yang terbelenggu oleh kekuatan kaum tiran. Mereka tidak punya kemerdekaan, tidak punya kebebasan berbicara terbuka, dan tidak punya hak untuk beroposisi. Mereka dibuat tak berdaya oleh praktik kesombongan, kecongkakan, dan ketakaburan kekuasaan yang diabsolutkan. Mereka memang hidup, tapi esensinya mereka mengisi peti mati. Faktanya mereka bisa sewaktu-waktu dirampas jiwa dan nyawanya secara biadab oleh penguasa dan jaringannya.

${ }^{10}$ Gunarto Suhardi, Perlindungan Hukum Bagi Para Pekerja Kontrak Outsourcing, (Yogyakarta: Universitas Atmajaya Yogyakarta,:2006), 1. 
Untuk mencegah kebiadaban atau ketidakamnusiawian oknum penguasa dan jaringannya (korporasi plat hitam) seperti pemilik modal jahat, akhirnya masing-masing segmen bangsa di dunia yang merasa punya komitmen moral untuk merespon dan melindungi HAM, akhirnya dibuatkan kovenan semisal UDHR dengan maksud mulia: memartabatkan kehidupan manusia, menyelamatkan manusia dari berbagai bentuk perilaku yang bermodus memperlakukannya secara tidak manusiawi, termasuk menempatkan alasan agama tertentu sebagai instrumen menindas atau tidak memanusiawikan tenaga kerja.

Pasal 2 (a) Cairo Declaration yang merupakan Deklarasi HAM Islam juga sejalan dengan UDHR tersebut, bahwa kehidupan adalah berkah Tuhan dan untuk hidup dijamin bagi setiap umat manusia. Adalah tugas dari setiap individu, masyarakat, dan negara untuk melindungi hak-hak ini dari setiap pelanggaran apapun dan dilarang untuk mencabut kehidupan, kecuali dibenarkan oleh syari'at.

Masing-masing negara yang telah menyetujui jadi negara penegak HAM dan hukum kemudian merumuskannya ke dalam hukum positipnya masing-masing. Hukum positip ini dimaksudkan untuk mengayomi, antara lain hak hidup rakyatnya dari berbagai bentuk perilaku yang membahayakan atau mengancam keselamatan, kesehatan dan kelangsungan hidupnya.

Produk hukum di bidang ketenagakerjaan yang dibuat juga untuk menjadi pijakan normative berupa perlindungan bagi keselamatan, kesehatan, dan keamanan kerja Kaum pekerja ini diberi pengayoman supaya ketika menjalankan kewajibannya di sector industri, pekerja dapat menjalakannya dengan maksimal. Jika pekerja mampu menunjukkan etos kerjanya dengan maksimal, maka niscaya produktifitasnya akan memenuhi target yang diinginkan oleh perusahaan. Jika perusahaannya memenuhi target, maka ini dapat menjadi indikasi pencerahan ekonomi bangsa.

Sayangnya, seringkali hukum yang berbasis perlindungan hak (HAM) pekerja tidak atau belum ditegakkan. Hukum ketenagakerjaan menyebutkan pihak yang terkait sangat luas yaitu tidak hanya mengenai pekerja dan pengusaha saja namun juga adanya pihak-pihak lain. Pihakpihak lain atau kondisi tertentu inilah yang terkadang mempengaruhi pengimplementasian atau penegakan proteksi terhadap hak ketenagakerjaan. ${ }^{11} 3$

Perusahaan lebih senang memilih jalur yang tak memanusiakan manusia dan melanggar hukum. Perusahaan gampang berdalih kalau apa yang diperbuat, misalnya dalam kasus rasionalisasi atau PHK, perusahaan

${ }^{11}$ Maimun, Hukum Ketenaga Kerjaan Suatu Pengantar, (JakartaL Pradnya Paramitha, 2007), 11. 
diposisikan sedang terancam pailit dan butuh diselamatkan dengan konsekuensi mengorbankan pekerja. Begitu pula misalnya ketika perusahaan sedang ditimpa musibah, itu disebabkan "human error"

Padahal, dibalik alasan human error ini, sebenarnya perusahaan telah melakukan apa yang disebut pengabaian dan "kejahatan" dalam hal managemen perusahaan, yang potensinya berdampak pada pelanggaran HAM. Tatkala aspek managemen ini diabaikan, mau tidak mau, nasib pekerjalah yang dipertaruhkan. Bagaimana mungkin kesehatan, keselamatan, dan keamanan kerjabisa dinikmati oleh pekerja, kalau perusahaan ternyata masih menjadikannya sebagai komoditi ekonomi yang mahal?

Kasus seperti yang menimpa tenaga kerja PT Petriwidada di Gresik hanya mencerminkan kondisi dunia perusahaan dan ketenagakerjaan di Indonesia saat ini yang masih sering dinodao oleh pemilik modalnya yang meninggikan keserakahan dan kebiadaban dibandingkan memberdayakan nilai-nilai peradaban serta kemanusiaan yang idealnya berpihak pada tenaga kerja.

Perusahaan yang demikian itu dapat dikategorikan telah melakukan pelanggaran HAM sebagaimana diatur dalam pasal 1 ayat 6 UU Nomor 39 Tahun 1999 tentang HAM 6.pelanggaran hak asasi manusia adalah setiap perbuatan seseorang atau kelompok orang termasuk aparat negara baik sengaja ataupun tidak disengaja, atau kelalaian yang secara melawan hukum mengurangi, menghalangi, membatasi, atau mencabut hak asasi manusia seseorang atau kelompok orangyang dijamin oleh Undang-undang ini dan tidak mendapatkan atau dikhawatirkan tidak akan memperoleh penyelesaian hukum yang adil dan benar, berdasarkan mekanisme hukum yang berlaku.

Pekerja bukanlah sekedar modal untuk membesarkan kaum kapital, tetapi juga nafas bagi kehidupan republik ini. Jika mereka didera sakitsakitan, tidak terjaga kesehatannya, apalagi sampai terampas nyawanya akibat pemilik modal atau perusahaan yang maniak keuntungan ekonomi tidak menegakkan hak keselamatannya, maka ini namanya perusahaan membenarkan pelanggaran HAM sebagai jalan tembus mengukuhkan kapitalisme. Dan dimanapun namanya kapitalisme, tentulah butuh ongkos kebiadaban.

Betapapun mulianya kovenan yang mengatur perlindungan hak asasi manusia diberlakukan, tetaplah tidak ada artinya ketika ambisi mengeruk keuntungan ekonomi berlipat ganda dilakukan dengan cara mengabaikan hak keselamatan tenaga kerja. Perlakuan teerhadap tenaga kerja wajib dilakukan oleh perusahaan dengan berbagai cara. 


\section{KESIMPULAN}

Berdasarkan deskripsi bahasan di atas dapatlah disimpulkan, bahwa dewasa ini masih menjadi suatu fenomena yang memprihatinkan mengenai lemahnya perlindungan terhadap tenaga kerja berlatar keragaman agama di bidang keselamatan kerja. Kalangan pemilik modal atau korporasi masih lebih sering memperlakukan tenaga kerja sebagai obyek dan bukan sebagai subyek kerja. Perlakuan perusahaan terhadap pekerja belum menunjukkan perhatian yang serius. Terbukti tidak sedikit kecelakaan kerja di perusahaan-perusahaan yang sebenarnya sudah memahami kewajibannya dalam melindungi keselamatan tenaga kerja.

Perusahaan masih lebih banyak yang mengamankan kepentingan modal dan target keuntungan ekonomi besar dibandingkan kepentingan perlindungan HAM. Keselamatan tenaga kerja masih lebih dikalahkan oleh kepentingan mengeruk keuntungan material. Cara perusahaan demikian jelas bertentangan dengan ajaran Islam dan HAM.

\section{DAFTAR PUSTAKA}

\section{Buku}

Adrian Sutedi, 2009, Hukum Perburuhan, JakartaL Sinar Grafika.

Gunarto Suhardi, 2006, Perlindungan Hukum Bagi Para Pekerja Kontrak

Outsourcing, Yogyakarta: Universitas Atmajaya Yogyakarta.

Haekal Madani, 2015, Hak-hak Buruh dalam Berbagai Perspektif, Jakarta: Miqrab Media.

Jazila Nasuha, 2014, Perlindungan Islam terhadap Tenaga Kerja yang Bekerja di Pasar Global, Jakarta: Hifagroup.

Maimun, 2007, Hukum Ketenaga Kerjaan Suatu Pengantar, Pradnya Paramitha, Jakartaa.

Peter Mahmud Marzuki, 2010, Penelitian Hukum, Jakarta, Prenada Media Group.

Soerjono Soekanto, 1981, Pengantar Penelitian Hukum, Jakarta, UI Press.

\section{Makalah}

Abdul Wahid, dkk, "Perlindungan Tenaga Kerja Indonesia dalam Kajian Agama Islam", Lembaga Kajian dan Pengembangan Sumberdaya Manusia, 15 Mei 2016. 
PROTEKSI TERHADAP HAK KESELAMATAN TENAGA KERJA BERLATAR MULTI AGAMA

DALAM PERSPEKTIF ISLAM DAN HAM (Bambang Satriya)

\section{Undang-undang}

Undang-undang Republik Indonesia Nomor 39 Tahun 1999 tentang Hak Asasi Manusia

Undang-undang Republik Indonesia Nomor 13 Tahun Tahun 2003 tentang Ketenagakerjaan. 